\title{
Determinants of Corporate Social Responsibility Disclosure: The Case of the Banking Sector in Vietnam
}

\author{
NGUYEN THI LIEN HUONG \\ Faculty of Finance and Banking \\ Thuongmai University \\ 79 Ho Tung Mau st., Hanoi \\ VIETNAM \\ DANG THI MINH NGUYET* \\ Faculty of Finance and Banking \\ Thuongmai University \\ 79 Ho Tung Mau st., Hanoi \\ VIETNAM \\ NGUYEN NGOC KHANH LINH \\ Faculty of Finance and Banking \\ Thuongmai University \\ 79 Ho Tung Mau st., Hanoi \\ VIETNAM \\ NGUYEN THI HIEN \\ Faculty of Mathematics \\ Thuongmai University \\ 79 Ho Tung Mau st., Hanoi \\ VIETNAM
}

DINH THI HA

Faculty of Management Information System and E-commerce

Thuongmai University

79 Ho Tung Mau st., Hanoi

VIETNAM

\begin{abstract}
This study aims to investigate the factors that influence corporate social responsibility disclosure (CSRD) in the banking sector in an emerging country. The quantitative model is estimated for a sample of banks in Vietnam for the period from 2013 to 2019. To explain the determinants of CSRD in banking, regression analysis using panel data was employed while taking bank size, bank age, financial performance, state ownership, and regulation as independent variables, and CSRD as a dependent variable. The results revealed that bank size, bank age, and regulation have positive impacts on CSRD, whereas state ownership has a negative impact, and financial performance was found to be insignificant. This study enriches the knowledge of CSRD, and it contributes empirical evidence of the impact of bank characteristics on CSRD. Particularly, empirical evidence suggests that regulation is an effective instrument for promoting the CSRD of banks in Vietnam. Therefore, the study identified the need for government regulation to increase disclosure because voluntary disclosure does not seem to be sufficient to achieve the desired results.
\end{abstract}

Keywords: CSR disclosure, Vietnamese banking sector, financial performance, state ownership, regulation Received: April 27, 2021. Revised: December 2, 2021. Accepted: January 15, 2022. Published: January 16, 2022. 


\section{Introduction}

Banks are profit-driven businesses. However, to make money, their operation must be focused on "public confidence" [1]. They are supposed to contribute more to this phase than other economic organization due to their market's uniqueness [2]. Given the above, the banking industry's adoption of the corporate social responsibility (CSR) principle is critical. Other sectors are reactive to CSR because of external stakeholder scrutiny, whereas the banking industry plays an indispensable role in a country's economic development and participates in constructive CSR practices [3]. Because banks rely heavily on their reputation as support for their lending activities and remain stable sources, becoming involved in environmentally responsible operations has been seen as a method to gain social legitimacy and enhance the banking industry's image [4]. As a result, financial institutions usually rank high on international CSR disclosure [5]. Banks rely heavily on their reputation to support their lending activities with adequately reliable sources, which in turn impact bank risk. As a result, becoming involved in environmentally responsible operations has been seen as a method for gaining social legitimacy and enhancing the banking industry's image.

Despite a growing interest in CSR, few studies have examined the CSR activities of banks in a developing economy from a multidimensional perspective. Most previous studies have focused on the problems in developed countries [6]. However, applying the research results for developed nations may not be appropriate for developing countries, because their legal and institutional backgrounds are different. Developing countries have a much weaker relationship between investor responsibility and employees, customers, and communities than do developed countries [7]. Furthermore, stakeholders in emerging markets may have less influence than in developed markets. Considering these facts, this study provides an exciting opportunity to deepen our knowledge of CSR in an emerging market context.

Over the past few years, Vietnam has been a country that is strongly committed to the implementation of sustainability goals through the promulgation of the Vietnam Sustainable Development Strategy, the Vietnam Sustainable Development Strategy for the 2011 to 2020 period, and most recently, the National Action Plan for the Implementation of the 2030 Agenda for Sustainable Development. The topic of CSR has become a significant concern for the Vietnamese Government and Vietnamese companies. However, the regulations, policies, practices, and disclosures on CSR in Vietnam are still in the early stages. The first step forward in CSR regulations in Vietnam is marked by the introduction of the Law on Securities 2006, which was amended and supplemented in 2010, and Circular 15/2015/TT-BTC issued on 06/10/2015 by the Ministry of Finance, replacing Circular No. 52/2012/TT-BTC to guide corporate sustainability information disclosure on the stock market. However, the disclosure of CSR information on the securities market still has some shortcomings, which may affect the transparency, publicity, and sustainable development of the Vietnam stock market [8]. These have caused many Vietnamese banks to declare CSR, but not voluntarily.

To close this research gap, we used a sample of 28 of the 37 banks operating in Vietnam, and we collected data from their annual reports to investigate the current corporate social responsibility disclosure (CSRD) situation and the factors that impact the banking industry's CSRD.

This study offers an interesting opportunity to investigate the current evidence of CSR in Vietnam. Thus, the results are particularly relevant for developing economies, where insight into CSR practices is still weak because these practices are perceived as philanthropic and where the state still holds a substantial share in the banks. Furthermore, by testing the impacts of factors such as bank size, bank age, financial performance, state ownership and regulations in an emerging country, the study adds to the literature and the understanding of banks' CSRD. In addition, there is a shortage of studies that measure CSR through multiple dimensions, especially in the banking sector. Therefore, we introduce a way to calculate the CSRD index by using data that is drawn from quantitative, qualitative, and narrative information in annual reports and that covers numerous aspects of CSR: community, environment, and employment. Finally, our findings can be of practical valuable for stockholders, policymakers, professional organizations, and the government in terms of implementing CSRD.

The overall structure of this study includes five sections. Whereas the first section is an introduction, Section 2 presents a literature review and the hypotheses. The sample, variables, and methods for estimating the models are all covered in Section 3. The fourth section analyses the results of the proposed model, and Section 5 provides a summary of the research findings. 


\section{Literature review and hypotheses}

Among the theories involved in CSRD, each CSR theory provides all the factors connected to earnings, political performance, social needs, and ethics [9]. Agency theory holds that agency costs arise from conflicts of interest and information asymmetries between a company's management and its stockholders; therefore, CSRD contributes significantly to a reduction in this asymmetry of information. Furthermore, in terms of legitimacy theory, CSRD is an instrument that legitimizes a business, and it is within reach of society [10]. On the other hand, stakeholder theory suggests that it is necessary for an organization to build good relationships with shareholders and stakeholders through CSR reports [11]. According to signalling theory, disclosing CSR information is a way to send a message to interested parties about the company's economic, environmental, and social situation [12]. In summary, according to Cormier, LapointeAntunes, \& Magnan (2015), CSRD is a complicated phenomenon that cannot be described by a single theory [13].

There may be drivers behind CSRD that achieve higher levels of application and ensure CSRD. Therefore, several hypotheses are proposed in the next part to identify significant determinants of CSRD.

\subsection{Bank size}

According to certain research, bank size and CSRD have a considerable positive correlation [14]. Larger banks have larger budgets available for the implementation of social and environmental activities and for the disclosure of this information in their publications to the community. Furthermore, in accordance with legitimacy theory, large enterprises usually draw greater attention to their operations, especially to their social and environmental impacts, so they may have to issue more voluntary disclosures to make their activities transparent [15]. Likewise, Mahadeo et al. (2011) suggested that larger firms are required to achieve higher-quality CSRD due to stakeholder demand in order to legitimize their activities. A larger size company will be able to improve financial performance which in turn rise CSRD [16]. Moreover, a larger bank size reduces the costs of reporting [14].

Based upon these theoretical and empirical grounds, we assume that larger banks are more likely to disclose CSR information. Therefore, the statement of the first hypothesis is as follows:

H1: Bank size has a positive impact on CSRD.

\subsection{Bank age}

According to prior research, bank age is one of the drivers of the CSRD index. The perspective of legitimacy theory holds that an institution's reputation is constructed over time [10]. Older banks attempt to enhance their reputations from this perspective by expanding CSR transparency and revealing more CSRD than others because they have more experience in identifying the resources that are necessary for their survival and for maintaining their reputation through their social actions [17]. Moreover, older banks are more publicly visible than younger ones, and therefore have greater incentive to publish CSR information to meet the community's expectations [17]. In this way, older banks gain competitiveness in the market and maintain their reputation in society. Similarly, [18] discovered a positive relationship between bank age and the CSRD of listed banks in Tunisia.

For the reasons mentioned above, a positive association between bank age and CSRD is expected, and the second hypothesis is as follows:

$\mathrm{H} 2$ : Bank age has a positive association with the bank's level of CSRD

\subsection{Financial performance}

Previous studies have determined that the relationship between a firm's financial performance and its CSR [19-20] has a favourable association with future financial performance [19]. This shows that present CSR actions have a long-term financial impact. Other studies have found that activities that represent the social responsibility of a company improve its profitability when there exists a competitive environment between businesses [20].

To explain this relationship, Legendre \& Coderre (2013) suggested that profitable corporations tend to provide CSR information to legitimize their operations [21]. Hence, financial performance may be an important factor for CSRD [22]. In addition, a profitable company's board of directors may want to expose more CSR strategies to the public to establish a favourable image [23]. Considering the negative side of CSR strategy, Ruhnke \& Gabriel supposed that profitable corporations are more financially sustainable for costly CSR initiatives and in assuring community CSRD statement reports [24].

As a result of the literature review, a third hypothesis is proposed. 
H3: There is a positive correlation between financial performance and CSRD.

\subsection{State ownership}

Only a few researchers have looked specifically at the association between ownership type and CSRD for state-owned businesses because this factor depends on the characteristics of each country. State-owned banks benefit from financial and regulatory favour because of their inherent political ties [25], and along with their profit maximization goal, they are pressured to pursue political and strategic aims [26]. Mohd Ghazali (2007) illustrated that firms with a share of state disclosed more CSR information in their annual reports [27]. With the great impact of political interference on the behaviour of companies, a high level of perceived leadership is expected to lead to suitable management efforts to meet government expectations. The government, as the majority shareholder of state-owned companies, has incentives to divert wealth to achieve social stability [28], which improves the disclosure of CSR information. Sharing the same view, a study by $\mathrm{Xu}$ and Zheng (2016) implemented this theory using a sample of listed Chinese enterprises, and found a significantly positive relationship between state ownership and the quality of CSRD [29].

In addition to studies that indicate a positive correlation between state ownership and CSRD, some published research finds a negative association between the two factors. Using sample data for Chinese listed firms, a study by Shahab (2018) demonstrated that firms with a share of the state tend to have a low level of CSRD [30]. This view is supported by Alotaibi \& Hussainey [31], who argue that governmental ownership reduces the CSR index of firms in Saudi Arabia.

However, in the context of Vietnam, state-owned banks can be expected to be more politically sensitive, as the activities of these banks are in the public eye. As a result, this form of bank may engage more in socially responsible activities to increase the visibility of social activities and thereby legitimize its existence. For that reason, the following hypothesis is proposed:

H4: There is a positive relationship between state-owned banks and CSRD.

\subsection{Regulations}

A government's involvement in institutionalizing CSR has been the subject of a growing body of research [32]. Furthermore, governments may encourage CSR through soft regulation that imposes indirect penalties, such as labelling programs or rewards [33].

Mandatory CSRD regulation has evolved as a critical instrument of government CSR policy in this setting. Transparency is promoted by this sort of policy, which decreases information gaps between firms and stakeholders [34]. Because firms may more readily evaluate themselves against rivals and foster debate about best practices or industry standards, transparency may inspire improvements in CSR operations [33]. More significantly, stakeholders may become more effective in recognizing CSR or imposing fines on companies that engage in immoral business practices [35]. Using a database of 24 OECD countries, Jackson et al. indicated that companies that are required to practice information transparency adopt significantly more CSRD [33].

In Vietnam, Circular 155/2015 from the Ministry of Finance, which presents "Guidelines on disclosure information on the stock market" is the most important document for regulating CSR. Therefore, this study anticipates a favourable correlation between regulations and CSR reporting before and after the time this document was issued. Besides, listing companies need to strictly comply with Security market regulations in CSR transparency. For these reasons, the following two hypotheses are proposed.

H5: Disclosure regulation has a significant positive association with CSRD.

H6: Listing status has a significant positive association with CSRD.

In short, the proposed conceptual model for the determinants of CSRD is depicted in Fig. 1.

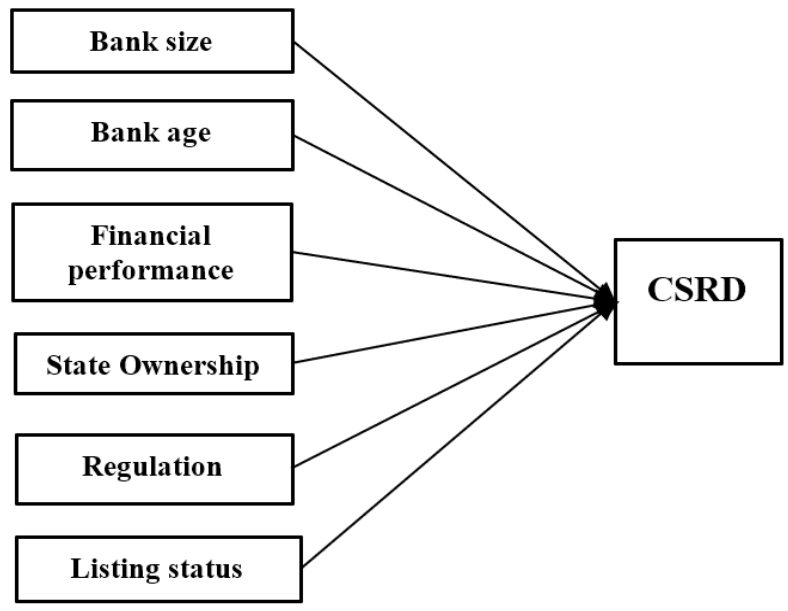

Fig. 1: Conceptual model: Determinants of CSRD Source: Author's research 


\section{Research methodology}

\subsection{Data and sample}

This study collected information relating to CSR from the annual reports of 28 Vietnamese banks during the period from 2013 to 2019, which included 196 observations.

We chose 2013 as the starting point of the research period, two years before the issuance of governmental guidelines for social responsibility information disclosure. The time range of the data extends to 2019 to ensure appropriate time coverage and to capture the changes in the CSR information disclosure of banks before and after governmental instruction. The research period is divided into two stages: the stage before Circular 155/2015 from the Ministry of Finance in Vietnam on "Guidelines on disclosure information on the stock market" and the time after Circular 155/2015 (2015 - 2019). In Vietnam, 2015 marked a change in the regulation of CSR information disclosure for banks. Therefore, it is necessary to evaluate the level of CSR information disclosure before and after 2015.

\subsection{Variables}

In this study, the level of CSRD in Vietnamese banks' annual reports is a dependent variable. This index is calculated based on the indicators of three criteria groups, which were built with reference to GRI (Global Reporting Initiative) standard combined with Circular 96/2020 and Circular 155/2015 of the Ministry of Finance of Vietnam on "Guidelines on disclosure of information on the stock market" and the document "Guidelines for making sustainable development reports" of the State Securities Commission in 2015. In each report, we are interested in information related to three categories of disclosure, concretized into a set of 29 indicators: community involvement disclosure that focuses on local community, including sponsorship and participation in educational, cultural, and other societal events (6 indicators); human resources disclosure consisting of information about the wellbeing of employees and benefits in the workplace (16 indicators); environmental disclosure, with a focus on banks' CSR efforts for environmental and natural resource protection (7 indicators).

Each indicator is qualitative data, and there is no superiority between and no difference in ranking among the different indicators. Therefore, to assess the level of information disclosure, we use a nominal scale with the following convention: First, the researcher detects the absence or existence of CSR information in relation to each indicator. Then, if the sample annual report contains an indicator included in the categories, it receives the value of 1 , or 0 otherwise. The numbers have no quantitative relationship and cannot be used for algebraic calculations. Their meaning indicates whether the indicators are included in the annual report of the banks. To assign values to each indicator, we identified several important keywords associated with each indicator for the information search. For example, the indicator "The sponsorship of arts, sports, and cultural activities" was associated with keywords such as "art," "sport," and "culture"; the indicator "Preferential loans and policies for employees" was associated with "preferential loans" and "incentives for employees" as keywords in the information search.

The CSRD represents the level of disclosure of corporate social responsibility in Vietnamese banks. It is calculated each year by the proportion of disclosed indicators out of total 29 indicators in three categories from the obtained data set, as follows:

$$
\operatorname{CSRD}=\frac{1}{e} \sum_{i=1}^{e} e_{i}
$$

Where:

CSRD can be expressed as a decimal or as a percentage. The value of CSRD is in the range $[0,1]$.

$e_{i}(i=1,2, \ldots, 29)$ : each $\mathrm{e}_{\mathrm{i}}$ represents each indication (as presented in Appendix 1). $e_{i}=1$ if the indication was published in the annual report of bank each year.

$\mathrm{e}=29$ : The maximum number of items a bank can disclose.

In addition, we also collected important data from the annual reports to analyse the determinants of the level of information disclosure by Vietnamese banks, such as bank size, bank age, financial performance, state ownership, listed bank or unlisted bank, and regulation between 2013 and 2019. A specific description of each independent variable in the regression model is presented in Table 1.

Table 1. Independent variables

\begin{tabular}{|c|c|c|c|}
\hline Var & $\begin{array}{c}\text { Variable full } \\
\text { name }\end{array}$ & $\begin{array}{c}\text { Predicted } \\
\text { sign }\end{array}$ & Measurement \\
\hline SIZE & Bank size & + & $\begin{array}{c}\text { Natural logarithm } \\
\text { of total assets }\end{array}$ \\
\hline AGE & Bank age & + & $\begin{array}{l}\text { The number of } \\
\text { operating years since } \\
\text { the bank was set up. }\end{array}$ \\
\hline ROE & $\begin{array}{c}\text { Financial } \\
\text { Performance }\end{array}$ & + & Return on equity \\
\hline STATE & $\begin{array}{c}\text { State } \\
\text { ownership }\end{array}$ & + & $\begin{array}{l}\text { STATE is a dummy } \\
\text { variable; if STATE }\end{array}$ \\
\hline
\end{tabular}




\begin{tabular}{|c|c|c|c|}
\hline REG & Regulation & + & $\begin{array}{c}=1, \text { bank has state } \\
\text { owner; if STATE }=0, \\
\text { otherwise. }\end{array}$ \\
\hline LIST & $\begin{array}{c}\text { LEG is a dummy } \\
\text { variable; if } \text { REG }=1, \\
\text { bank is listed after } \\
2015 ; \text { if } \text { REG }=0, \\
\text { otherwise. }\end{array}$ \\
\hline status & + & $\begin{array}{c}\text { LIST is a dummy } \\
\text { variable; if LIST }=1, \\
\text { bank is listed, if LIST } \\
=0, \text { bank is unlisted }\end{array}$ \\
\hline
\end{tabular}

Source: Author's research

\subsection{Empirical model}

According to the hypotheses mentioned above, we propose a multivariable linear regression model with panel data, in which the independent variables represent six factors affecting the information disclosure of the Vietnamese banks (Table 1).

$\operatorname{CSRD}_{\text {it }}=\beta_{0}+\beta_{1}$ SIZE $_{i t}+\beta_{2}$ AGE $_{\text {it }}+\beta_{3}$ ROE $_{\text {it }}+$

$\beta_{4}$ STATE $_{\text {it }}+\beta_{5}$ REG $_{\text {it }}+\beta_{6} \mathrm{LIST}_{\text {it }}+\varepsilon_{\text {it }}$.

(2)

Where:

$i$ denotes banks and $t$ represents time periods; $C S R D_{i t}$ is CSRD of bank $i$ at time $t$;

$\beta_{0}$ is the intercept; $\beta_{j}(j=1, \ldots, 6)$ is the regression coefficient;

$\varepsilon_{i t}$ is random error, which has an expectation of 0 and a variance that does not change.

The model was estimated by using the least squares method and data was analysed on Stata software.

\section{Result}

\subsection{Descriptive statistics}

To evaluate the level of CSRD of the banks in Vietnam based on their annual reports from 2013 to 2019 , this study applied a content analysis approach.

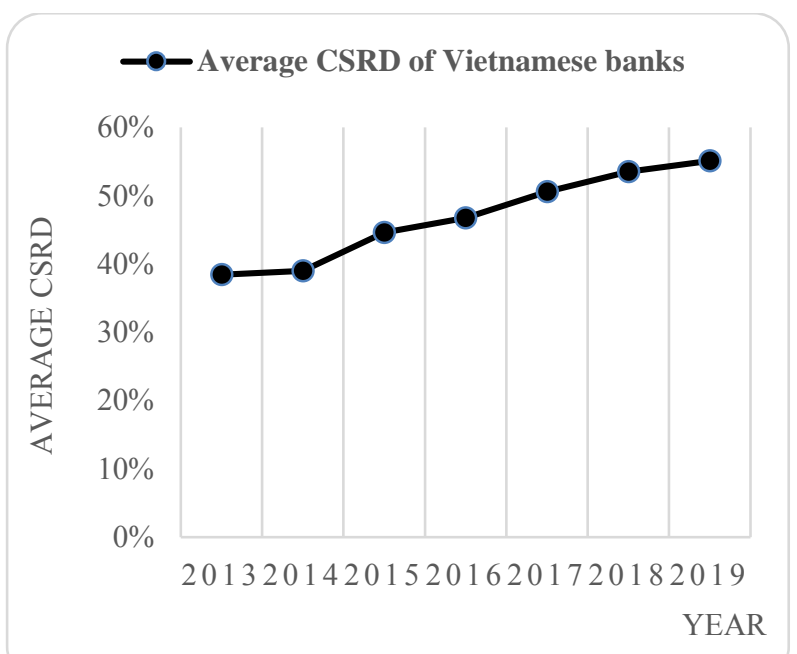

Fig. 2: Average CSRD of Vietnamese banks between 2013 and 2019

Source: Author's research

Figure 2 clearly illustrates a steady rise in banks' average level of information disclosure over the survey period, with a significant rise from $39.4 \%$ in 2013 to approximately $60 \%$ in 2019 . The level of CSRD in 2015 was noticeably higher than the level of the two previous years by approximately $5 \%$. This can be explained by the fact that at the end of 2014, there were issuances of several governmental guidelines on CSR information disclosure.

Table 2. Descriptive statistics by year

\begin{tabular}{cccccccc}
\hline YEAR CSRD & SIZE & AGE & ROE & STATE & REG & LIST \\
\hline 2013 & 0.394 & 18.37 & 21.8 & 0.056 & 0.18 & 0.00 & 0.29 \\
2014 & 0.401 & 18.51 & 22.8 & 0.059 & 0.18 & 0.00 & 0.32 \\
2015 & 0.446 & 18.62 & 23.8 & 0.054 & 0.18 & 0.29 & 0.32 \\
2016 & 0.488 & 18.78 & 24.8 & 0.074 & 0.18 & 0.29 & 0.32 \\
2017 & 0.532 & 18.96 & 25.8 & 0.101 & 0.18 & 0.36 & 0.43 \\
2018 & 0.570 & 19.07 & 26.8 & 0.106 & 0.18 & 0.43 & 0.50 \\
2019 & 0.599 & 19.20 & 27.8 & 0.118 & 0.18 & 0.43 & 27.8 \\
\hline
\end{tabular}

Source: Author's research

The following Table 2 shows that the average financial performance and size of banks increased over time. In particular, the average financial performance of banks doubled. The statistical results also indicate that the average rate of listed banks showed an upward trend and rose at a faster pace after 2017, while the percentage of state-owned banks remained unchanged during the study period.

Table 3. Descriptive statistics of key variables 


\begin{tabular}{lccccc} 
CSRD & 196 & 0.49 & 0.92 & 0.00 & 0.259 \\
SIZE & 196 & 18.8 & 21.1 & 16.5 & 1.092 \\
AGE & 196 & 24.8 & 62.0 & 5.00 & 10.26 \\
ROE & 196 & 0.08 & 0.66 & 0.0008 & 0.079 \\
STATE & 196 & 0.18 & 1.00 & 0.00 & 0.384 \\
REG & 196 & 0.26 & 1.00 & 0.00 & 0.437 \\
LIST & 196 & 0.38 & 1.00 & 0.00 & 0.487 \\
\hline
\end{tabular}

Source: Author's research

Table 3 summarizes information about the number of observations and descriptive statistics of key variables in the model. The figure reveals that the banks disclosed $50 \%$ of the indicators in the three groups. The oldest bank in Vietnam has been operating for 62 years, and the youngest bank in the sample has been established for 5 years. The proportion of banks with state-owned capital in Vietnam is not large, averaging about $18 \%$. The financial performance of banks in Vietnam was quite low, with an average ROE of approximately $8.1 \%$.
The correlations between the different variables in our study are illustrated in Table 4. Except for the strong correlation between LIST and REG (at around 0.74), other explanatory variables were found to have low correlation, with all correlation values below 0.6 . These results illustrate that there was no multicollinearity problem in our case.

Regarding the correlation matrix, we noted that CSR was positively correlated with all explanatory variables. These results are in agreement with the analysis in Table 2. Banks that have been operating for a long time, have a large size, high debt, are listed on the stock exchange, and have good financial performance show high information disclosure.

\begin{tabular}{|c|c|c|c|c|c|c|c|}
\hline Variables & CSRD & BKSIZE & AGE & ROE & STATE & LIST & REG \\
\hline CSRD & 1 & & & & & & \\
\hline BKSIZE & $0.3384 * * *$ & 1 & & & & & \\
\hline AGE & $0.3081 * * *$ & $0.5441 * * *$ & 1 & & & & \\
\hline ROE & $0.2508 * * *$ & $0.4173 * * *$ & $0.2618 * * *$ & 1 & & & \\
\hline STATE & 0.0871 & $0.6402 * * *$ & $0.5291 * * *$ & 0.0991 & 1 & & \\
\hline LIST & $0.2518^{* * *}$ & $0.5178 * * *$ & $0.355 * * *$ & $0.2035 * * *$ & $0.1811 * *$ & 1 & \\
\hline REG & $0.3215^{* * *}$ & $0.4679 * * *$ & $0.403 * * *$ & $0.1628 * *$ & $0.1855 * * *$ & $0.7433 * * *$ & 1 \\
\hline
\end{tabular}

Table 4. Pearson correlation matrix

$(*, * *, * * *$ represent the significance level of $10 \%, 5 \%$, and $1 \%$, respectively)

Source: Author's research

\subsection{Estimation results}

The coefficients in model (1) are estimated by the panel least-squares method, and the results are presented in Table 5.

It can be inferred from the table that ROE and LIST are two variables that are not statistically significant. For that reason, the hypotheses regarding the positive correlations of CSRD and banking profitability and listing status are not in line with the data for banks in Vietnam during the given period. The results illustrate a significant positive correlation of the banks' total assets with CSRD at a $1 \%$ significance level in terms of bank size.
Table 5. Results of the multivariate regression model

\begin{tabular}{ccc}
\hline Variables & Coefficient & P_value \\
\hline C & -1.0223 & 0.0325 \\
SIZE & 0.0736 & 0.0062 \\
AGE & 0.0051 & 0.0171 \\
ROE & 0.2640 & 0.2815 \\
STATE & -0.1660 & 0.0109 \\
REG & 0.1218 & 0.0418 \\
LIST & -0.0561 & 0.3051 \\
R-squared & 0.2058 & \\
Adjusted R-squared & 0.1806 & \\
\hline
\end{tabular}

Source: Author's research

Table 5 also presents a positive impact of bank age on CSR reporting. In addition, the figures from Table 5 illustrate a significant positive association between the REG variable and the CSRD index at a $5 \%$ significance level. 
The REG variable differentiates between banks listed before and after 2015 to determine whether the regulations relating to CSRD issued in 2014 and 2015 for the listed firms affect the way banks publish their information. Therefore, the results from Table 5 suggest that governmental regulations raised the CSRD quality of banks in Vietnam.

Table 6. Results of heteroscedasticity LR test

\begin{tabular}{cccc}
\hline \multicolumn{4}{c}{ Panel Period Heteroscedasticity LR Test } \\
\hline Null hypothesis: Residuals are homoscedastic \\
Specification: CSRD C SIZE ROE STATE LIST REG AGE \\
Value & df & P-Value \\
Likelihood ratio & 2.74 & 28 & 1.000 \\
Source: Author's research
\end{tabular}

We can see that the model indicates the heteroscedasticity phenomenon. To overcome this problem, we use the weighted least-squares method. The results of the fixed model are as follows (Table 7).

Table 7. Results of the fixed model

\begin{tabular}{ccc}
\hline Variable & Coefficient & P_value \\
\hline C & -1.0446 & 0.0275 \\
SIZE & 0.0749 & 0.0049 \\
ROE & 0.2648 & 0.2682 \\
STATE & -0.1688 & 0.0089 \\
LIST & -0.0600 & 0.2459 \\
REG & 0.1262 & 0.0339 \\
AGE & 0.0053 & 0.0125 \\
R-squared & 0.2195 & \\
Adjusted R-squared & 0.1948 & \\
Source: Author's research &
\end{tabular}

\subsection{Discussion}

Based on the results, we present the following discussions.

Firstly, regarding Table 2, it can be implied that the level of CSRD of Vietnamese banks is improving over time. In addition, the considerable rise in 2015 indicates the positive impact of the guidelines on stock market information disclosure in the way banks publish their CSR information. This implies that the issuance of a policy on sustainability disclosure has a significant impact on the CSRD of banks.

Secondly, bank size and bank age all positively affect the CSRD index. These results are in agreement with legitimacy theory and the findings of Mahadeo [15] that larger firms are required to public higher quality CSRD due to stakeholder demand to legitimize their activities, and that older banks with longer experience in reporting may disclose more CSR information [18].

Thirdly, there is a significant negative association between state ownership and CSRD, meaning that firms with a state share tend to maintain a low level of CSRD. This result is an exciting finding of the study, which is different from Hypothesis 4 proposed above. However, this finding is compatible with the study implemented by Shahab [30] and Alotaibi et al. [31], indicating that a higher percentage of state ownership may be related to poor corporate governance, which includes the implementation of CSRD. Furthermore, another explanation for this may come from the fact that state-owned banks have a higher rank in comparison with commercial banks in terms of bank size or reputation, and they have greater opportunities to receive government priority. For that reason, they do not have incentives to disclose CSR information, which is considered a costly and time-consuming process.

Fourthly, contrary to earlier findings [20, 24], there is no evidence of a statistical association between financial performance and CSRD. One possible reason for this is that Vietnam is in the very first stage of CSRD, and banks mostly focus on their economic goals rather than on spending time and money on social and environmental programs. Therefore, the profitability of banks does not yet have any impact on CSRD.

Finally, regulation shows a significant impact on CSRD index. Only when the stock market applies regulations on CSRD do banks increase their CSR information disclosure. An implication of this finding is that voluntary disclosure in developing nations may not be sufficient to ensure the quality of information disclosure. Therefore, it is necessary for governmental authorities to issue additional regulations relating to environmental and social activities.

\section{Conclusion}

This research provided insight into how emerging nations, particularly Vietnam, handle CSRD in the banking industry. It makes four significant additions to the literature on corporate transparency. First, by investigating the effects of bank size, bank age, financial performance, state ownership, and regulation in an emerging country, the study contributes to an understanding of the level of banks' CSRD in Vietnam. Second, there is a scarcity of research that measures CSR across various dimensions, particularly in the banking industry. 
Therefore, we employed the CSRD index, which is based on quantitative, qualitative, and narrative data from yearly sustainability reports and covers a wide range of CSR topics: community, environment, and job opportunities. We also adjusted the CSR criteria to suit the Vietnamese context. Third, bank size, bank age and regulation are the most effective instruments for increasing CSRD in emerging countries. Therefore, investors, policymakers, and the government can benefit from this research regarding CSRD in the banking sector in Vietnam. This underscores the need for the Vietnamese Government to introduce additional CSRD guidelines towards the goal of sustainable development.

\section{References:}

[1] KRASODOMSKA, Joanna. CSR disclosures in the banking industry. Empirical evidence from Poland. Social Responsibility Journal, 2015, 11.3: 406-423.

[2] KORENIK, Dorota. Macroeconomic responsibility versus social responsibility of a modern commercial bank-theoretical and cognitive aspect. Economics \& Management, 2010, p118-122. 5p.

[3] DECKER, O. Sallyanne. Corporate social responsibility and structural change in financial services. Managerial Auditing Journal, 2004, 19.6: 712-728.

[4] GANGI, Francesco, Antonio Meles, Eugenio D'Angelo, and Lucia Michela Daniele. Sustainable development and corporate governance in the financial system: Are environmentally friendly banks less risky?. Corporate Social Responsibility and Environmental Management, 2019, 26.3: 529547.

[5] PÉREZ, Andrea; DEL BOSQUE, Ignacio Rodríguez. Measuring CSR image: Three studies to develop and to validate a reliable measurement tool. Journal of business ethics, 2013, 118.2: 265-286.

[6] ABAD-SEGURA, Emilio; CORTÉS-GARCÍA, Francisco Joaquín; BELMONTE-UREÑA, Luis J. The sustainable approach to corporate social responsibility: A global analysis and future trends. Sustainability, 2019, 11.19: 5382.

[7] ALI, Waris; FRYNAS, Jedrzej George; MAHMOOD, Zeeshan. Determinants of corporate social responsibility (CSR) disclosure in developed and developing countries: A literature review. Corporate Social
Responsibility and Environmental Management, 2017, 24.4: 273-294.

[8] TRAN, Trung Tin. Corporate social responsibility (CSR) situation in Vietnam. 2017. PhD Thesis. Saimaan ammattikorkeakoulu.

[9] GARRIGA, Elisabet; MELÉ, Domènec. Corporate social responsibility theories: Mapping the territory. Journal of business ethics, 2004, 53.1: 51-71.

[10] CRAIG, Deegan. Introduction. The legitimising effect of social and environmental disclosures-a theoretical foundation. Accounting, Auditing \& Accountability Journal, 2002, 15.3: 282-311.

[11] LOURENÇO, Isabel C.; BRANCO, Manuel Castelo. Determinants of corporate sustainability performance in emerging markets: the Brazilian case. Journal of Cleaner Production, 2013, 57: 134-141.

[12] SPENCE, Michael. Signaling in retrospect and the informational structure of markets. American Economic Review, 2002, 92.3: 434-459.

[13] CORMIER, Denis; LAPOINTE-ANTUNES, Pascale; MAGNAN, Michel. Does corporate governance enhance the appreciation of mandatory environmental disclosure by financial markets?. Journal of Management \& Governance, 2015, 19.4: 897-925.

[14] JENNIFER HO, Li- Chin; TAYLOR, Martin E. An empirical analysis of triple bottom- line reporting and its determinants: evidence from the United States and Japan. Journal of International Financial Management \& Accounting, 2007, 18.2: 123-150.

[15] MAHADEO, Jyoti Devi; OOGARAHHANUMAN, Vanisha; SOOBAROYEN, Teerooven. Changes in social and environmental reporting practices in an emerging economy (2004-2007): Exploring the relevance of stakeholder and legitimacy theories. In: Accounting Forum. Taylor \& Francis, 2011. p. 158-175.

[16] ORBANINGSIH, D., SAWITRI， D. and SUHARSONO, R.S., 2021. Determinants of Corporate Social Responsibility Disclosure: A Case Study of Banking Industry in Indonesia. The Journal of Asian Finance, Economics and Business, 8(5), pp.91-97.

[17] BACCOUCHE, C.; ERRAÏS, O.; MZOUGHI, K. Determinants of voluntary CSR reporting: the case of Tunisian companies." Intangible Capital: status and prospects, Montpellier, 2010. 
WSEAS TRANSACTIONS on BUSINESS and ECONOMICS DOI: 10.37394/23207.2022.19.30

[18] CHAKROUN, Raida, et al. Determinants of CSR disclosure of Tunisian listed banks: a multi-support analysis. Social Responsibility Journal, 2017, 13.3: 552-584.

[19] HARUN, Mohd Shukor, et al. CSR Disclosure, Corporate Governance and Firm Value: a study on GCC Islamic Banks. International Journal of Accounting and Information Management, 2020, 28.4: 607-638.

[20] KIM，Kwang-Ho; KIM, MinChung; QIAN, Cuili. Effects of corporate social responsibility on corporate financial performance: A competitive-action perspective. Journal of Management, 2018, 44.3: 1097-1118.

[21] LEGENDRE, Stéphane; CODERRE, François. Determinants of GRI G3 application levels: the case of the fortune global 500. Corporate Social Responsibility and Environmental Management, 2013, 20.3: 182-192.

[22] AKSU, Mine; KOSEDAG, Arman. Transparency and disclosure scores and their determinants in the Istanbul Stock Exchange. Corporate Governance: An International Review, 2006, 14.4: 277-296.

[23] ALSAEED, Khalid. The association between firm-specific characteristics and disclosure: The case of Saudi Arabia. Managerial Auditing Journal, 2006, 21.5: 476-496.

[24] RUHNKE, Klaus; GABRIEL, Alexander. Determinants of voluntary assurance on sustainability reports: an empirical analysis. Journal of Business Economics, 2013, 83.9: 1063-1091.

[25] WU, Shihwei; LIN, Fengyi; WU, Chiaming. A study on Taiwanese corporate social responsibility and ownership structures. Corporate Ownership and Control, 2012, 9.3: 111-122.

[26] HU, Yuan Yuan, et al. Ownership influence and CSR disclosure in China. Accounting Research Journal, 2018, 31.1: 8-21.

[27] GHAZALI, Nazli A. Mohd. Ownership structure and corporate social responsibility disclosure: some Malaysian evidence. Corporate Governance: The international journal of business in society, 2007.

[28] BAI, Chong-En; LU, Jiangyong; TAO, Zhigang. The multitask theory of state enterprise reform: Empirical evidence from China. American Economic Review, 2006, 96.2: 353-357.

[29] XU, Bixia; ZENG, Tao. Profitability, state ownership, tax reporting and corporate social responsibility: evidence from Chinese listed firms. Social Responsibility Journal, 2016, 12.1: 23-31.

[30] SHAHAB, Yasir; YE, Chengang. Corporate social responsibility disclosure and corporate governance: empirical insights on neoinstitutional framework from China. International Journal of Disclosure and Governance, 2018, 15.2: 87-103.

[31] ALOTAIBI, Khaleed Omair; HUSSAINEY, Khaled. Determinants of CSR disclosure quantity and quality: Evidence from nonfinancial listed firms in Saudi Arabia. International Journal of Disclosure and Governance, 2016, 13.4: 364-393.

[32] DENTCHEV, Nikolay A.; VAN BALEN, Mitchell; HAEZENDONCK, Elvira. On voluntarism and the role of governments in CSR: Towards a contingency approach. Business Ethics: A European Review, 2015, 24.4: 378-397.

[33] JACKSON, Gregory, et al. Mandatory nonfinancial disclosure and its influence on CSR: An international comparison. Journal of Business Ethics, 2020, 162.2: 323-342.

[34] HESS, David. The future of sustainability reporting as a regulatory mechanism. In: Law and the transition to business sustainability. Springer, Cham, 2014. p. 125-139.

[35] FERNANDEZ-FEIJOO, Belen; ROMERO, Silvia; RUIZ, Silvia. Effect of stakeholders' pressure on transparency of sustainability reports within the GRI framework. Journal of business ethics, 2014, 122.1: 53-63.

\section{Author Contributions:}

Nguyen Thi Lien Huong carried out the Literature Review and reviewed final version.

Dang Thi Minh Nguyet has implemented the Introduction.

Nguyen Ngoc Khanh Linh carried out the discussion and has reviewed first draft.

Nguyen Thi Hien was responsible for methodology. Dinh Thi Ha has organized the result.

\section{Sources of funding:}

This research was funded by Vietnam Ministry of Education and Training and Thuongmai University under grant number B2020-TMA-03

\section{Creative Commons Attribution License 4.0 (Attribution 4.0 International, CC BY 4.0)}

This article is published under the terms of the Creative Commons Attribution License 4.0

https://creativecommons.org/licenses/by/4.0/deed.en_US 


\section{APPENDIX}

Table 8. Elements of CSR disclosure

\begin{tabular}{|c|c|c|}
\hline Group & Code & Elements \\
\hline \multirow{6}{*}{$\begin{array}{l}\text { Disclosures of } \\
\text { community } \\
\text { involvement }\end{array}$} & COM01 & Donation to public health \\
\hline & COM02 & Sponsorship to arts, sports and culture \\
\hline & COM03 & Donation to education and training \\
\hline & COM04 & Donation to environmental protection programs \\
\hline & COM05 & Assistance to vulnerable groups (women, orphanage, disabled etc) \\
\hline & COM06 & Charity and other community activities \\
\hline \multirow{16}{*}{$\begin{array}{l}\text { Disclosures of } \\
\text { human } \\
\text { resource }\end{array}$} & EMP01 & Training, seminar and workshop for employees \\
\hline & EMP02 & Number of employees receive the training \\
\hline & EMP03 & Employee academic level \\
\hline & EMP04 & Internship program for university students \\
\hline & EMP05 & Credit facilities under various loan policies \\
\hline & EMP06 & Employee remuneration \\
\hline & EMP07 & Employee family welfare \\
\hline & EMP08 & Good working environment \\
\hline & EMP09 & Employee health and safety \\
\hline & EMP10 & Employee recreation \\
\hline & EMP11 & Equal opportunities for employees \\
\hline & EMP12 & Employee satisfaction \\
\hline & EMP13 & Employee profitability \\
\hline & EMP14 & Policy compliance \\
\hline & EMP15 & Employees recruitment procedure \\
\hline & EMP16 & Number of employees \\
\hline \multirow{7}{*}{$\begin{array}{l}\text { Disclosures of } \\
\text { Environment }\end{array}$} & ENV01 & Environmental standard consideration for extending loan \\
\hline & ENV02 & Promoting environmental awareness \\
\hline & ENV03 & Environmental protection activities \\
\hline & ENV04 & $\begin{array}{l}\text { Application of "Environmental and social risks management programs" } \\
\text { by the State Bank of Vietnam }\end{array}$ \\
\hline & ENV05 & Working environment \\
\hline & ENV06 & Environmental policies \\
\hline & ENV07 & Compliance with environmental protection policy of the government \\
\hline
\end{tabular}

